\title{
Effect of Diet and Triiodothyronine on the
}

\section{Activity of sn-Glycerol-3-Phosphate}

\section{Dehydrogenase and on the Metabolism of Glucose and}

\section{Pyruvate by Adipose Tissue of Obese Patients}

\author{
G. A. Bray with the technical assistance of Stella Mothon and \\ ANDREa CoHEN \\ From the New England Medical Center Hospitals and the Department of \\ Medicine, Tufts University School of Medicine, Boston, Massachusetts 02111
}

A B S T R A C T Lipogenesis and the metabolism of snglycerol-3-phosphate were studied in 23 fat biopsies from eight grossly obese patients. The first biopsy was obtained after a minimum of 12 days on a 3500 cal diet, the second biopsy after 2 wk on a $900 \mathrm{cal} \mathrm{diet,} \mathrm{and} \mathrm{the}$ third biopsy after an additional 2 wk on 900 cal supplemented with triiodothyronine, $250 \mu \mathrm{g} /$ day.

Oxygen consumption and respiratory quotient declined during caloric restriction. Oxygen consumption was restored to the initial level during treatment with triiodothyronine, and the respiratory quotient rose somewhat.

Lipogenesis from glucose and pyruvate was demonstrated in fat obtained from the first biopsy but could not be detected in the other biopsies. The incorporation of radioactivity from pyruvate into fatty acids was stimulated by the addition of glucose.

Insulin stimulated lipogenesis in pieces of fat from the first biopsy, but isolated fat cells were unaffected by insulin. After caloric restriction no effects of insulin could be detected.

The activity of both the cytoplasmic and mitochondrial sn-glycerol-3-phosphate dehydrogenase in homogenates of adipose tissue declined with caloric restriction. Treatment with triiodothyronine enhanced the activity of the mitochondrial sn-glycerol-3-phosphate dehydrogenase but did not affect the cytoplasmic enzyme.

\section{INTRODUCTION}

In recent studies from this laboratory, it was shown that mitochondria from subcutaneous fat of obese pa-

Received for publication 7 January 1969 and in revised form 19 March 1969. tients oxidized sn-glycerol-3-phosphate at a reduced rate (1). This finding may provide a metabolic basis for the development of obesity, since sn-glycerol-3-phosphate is an obligatory acyl acceptor for the synthesis of triglycerides $(2,3)$. Depressed oxidation of this substrate by mitochondria might be expected to enhance the development of obesity by increasing the supply of sn-glycerol-3-phosphate for synthesis of triglyceride. The metabolism of sn-glycerol-3-phosphate can be increased in experimental animals by treatment with thyroid hormones $(4,5)$ and manipulation of dietary intake (6). The present studies were designed to determine whether similar manipulations could alter the metabolism of sn-glycerol-3-phosphate in adipose tissue from obese patients. To this end eight obese patients were biopsied on each of three occasions. The first biopsy was done after 12-21 days on a $3500 \mathrm{cal}$ diet, the second biopsy was performed after a period of 2-3 wk on 900 cal, and the final biopsy was taken after triiodothyronine was added. With this experimental design (Fig. 1), it was possible to compare the effect of two levels of caloric intake and a third period with triiodothyronine on the activity of the soluble and mitochondrial snglycerol-3-phosphate dehydrogenases. This experimental design also afforded an opportunity to explore the effects of dietary intake and triiodothyronine on lipogenesis from pyruvate and glucose by adipose tissue in vitro.

\section{METHODS}

Experimental plan. Fig. 1 presents the experimental design of these studies. Five patients were hospitalized on the Clinical Study Unit of the New England Medical Center Hospitals, and three were hospitalized on the metabolic ward of the Lemuel Shattuck Hospital. All patients were fed $3500 \mathrm{cal} /$ day for the first period varying from 12 to 21 days. 


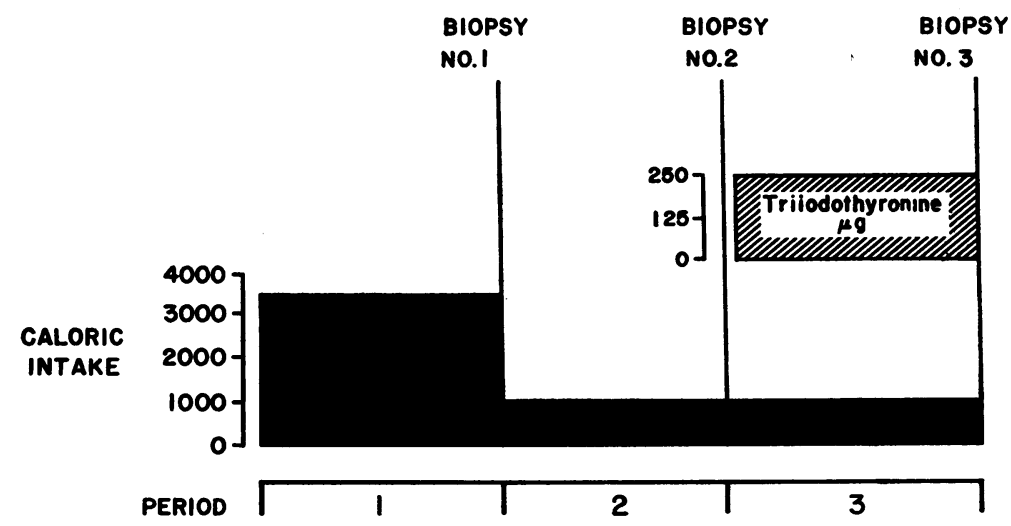

Figure 1 Experimental design. Period 1 ranged from 12 to 21 days, period 2 from 12 to 16 days, and period 3 from 14 to 18 days.

One patient had ingested $5000-7000$ cal daily for 6 wk under metabolic observation before the present study was begun. Oxygen consumption and respiratory quotient were measured on the five patients hospitalized at the New England Medical Center Hospitals by collecting three to eight samples of expired air in Douglas bags (Douglas Laboratories, Inc., Evanston, Ill.), at preset times during the day. Each sample was analyzed for volume with a Precision Wet Test Meter (Precision Scientific Co., Chicago, III.) and for the concentration of $\mathrm{O}_{2}$ (Beckman Oxygen Analyzer, model E 2) and $\mathrm{CO}_{2}$ (Godart Capnograph). The 3500 cal diet was calculated from standard tables, and the 900 cal diet was provided as a liquid formula ${ }^{1}$ containing $50 \%$ of the calories as carbohydrate. All fat biopsies were performed on the Clinical Study Unit of the New England Medical Center Hospitals after an overnight fast. Fat was obtained through an abdominal incision with intradermal local anesthesia. Care was taken not to introduce the anesthetic agent (1\% Xylocaine) below the dermis unless absolutely necessary. With this technique it was possible to remove $15-30 \mathrm{~g}$ of fat without difficulty. These samples arrived in the laboratory within $5 \mathrm{~min}$.

After the first biopsy the caloric intake was reduced to $900 \mathrm{cal}$ of a liquid formula diet and measurements of oxygen consumption, and respiratory quotient were again obtained toward the end of the 12-16 days of this period. At the end of the second period another fat biopsy was secured from the opposite side of the abdomen. In the third period triiodothyronine, $250 \mu \mathrm{g} / \mathrm{day}$, was added while the caloric intake was maintained at $900 \mathrm{cal}$ for an additional 14-18 days. Measurements of oxygen consumption and the performance of a third fat biopsy were obtained at the end of the period as described above.

Incubation procedures. For the in vitro studies two different preparations of fat were used. The first preparation consisted of thin pieces of fat weighing between 120 and $140 \mathrm{mg}$ which were cut from the intact biopsy with sharp dissecting scissors. Incubations with this preparation were begun within $10-20 \mathrm{~min}$ after removing the fat. The second preparation consisted of fat cells prepared by digestion of minced fat in $3 \mathrm{ml}$ of Krebs-Ringer bicarbonate buffer containing approximately $10 \mathrm{mg}$ of Collagenase (Worthington Corporation, Harrison, N. J.) as described by Rodbell (7), except that albumin was omitted from the

\footnotetext{
${ }^{1}$ Metrecal, Mead-Johnson \& Co., Evansville, Ind.
}

digestion mixture. After a 20-30 min incubation the pieces of fat were broken up and the fat cells washed five times with buffer, and samples equivalent to $100-150 \mathrm{mg}$ of triglyceride were used for incubations.

All incubations were carried out in $1 \mathrm{ml}$ of Krebs-Ringer bicarbonate buffer, $\mathrm{pH} 7.4 \pm 0.1$, containing $40 \mathrm{mg}$ of albumin (Armour Pharmaceutical Co., Chicago, Ill. lot D 26102), which was present as an acceptor for free fatty acids. When the response to insulin was being measured, $2 \mathrm{~mm}$ glucose-

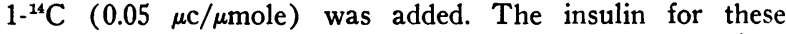
experiments was diluted from commercial preparations (Lilly Crystalline Insulin, Eli Lilly \& Co., Indianapolis, Ind.). In the remaining experiments $5 \mathrm{~mm}$ pyruvate $-3{ }^{14} \mathrm{C}$ $(0.02 \mu \mathrm{c} / \mu$ mole $)$ was added to the incubation medium. Insulin, $625 \mu \mathrm{U} / \mathrm{ml}$, and (or) $2 \mathrm{mM}$ glucose was present in some of the vials containing pyruvate. All vials were incubated in an atmosphere of $95 \% \quad \mathrm{O}_{2}, 5 \% \quad \mathrm{CO}_{2}$ at $37^{\circ} \mathrm{C}$ for periods of time ranging from 30 to $180 \mathrm{~min}$. At the end of the incubation $0.5 \mathrm{ml}$ of Hyamine (Packard Instrument Co., Inc., Downers Grove, Ill.) was added to a filter paper wick in a polyethylene cap suspended from the top of each vial, and $0.5 \mathrm{ml}$ of $0.5 \mathrm{~N}$ sulfuric acid was added to the incubation medium. The vials were shaken for an additional hour to collect $\mathrm{CO}_{2}$, and the radioactivity was assayed in a liquid scintillation counter after which the counts were corrected for quenching by adding internal standards. The total lipid in the incubation medium of the fat cells was extracted into $4 \mathrm{ml}$ of heptane (8). The pieces of fat were crushed in Dole's extraction fluid (8) and then extracted into heptane.

TABLE I Clinical Data

\begin{tabular}{ccccccccc}
\hline & & & & & \multicolumn{3}{c}{ Weight loss } \\
\cline { 5 - 8 } $\begin{array}{c}\text { Patient } \\
\text { No. }\end{array}$ & Sex & Age Height & Weight & Period 1 & Period 2 & Period 3 \\
\hline & & $y r$ & in. & $k g$ & & $k g$ & \\
1 & F & 25 & 63 & 138.9 & +4.0 & -9.0 & -7.7 \\
2 & F & 26 & 65 & 131.2 & +7.5 & -8.3 & - \\
3 & F & 31 & 64 & 149.5 & +10.0 & -9.6 & -7.1 \\
4 & F & 42 & 67 & 190.4 & -7.0 & -9.1 & -10.6 \\
5 & M & 17 & 69 & 142.7 & 0.0 & -5.6 & -13.8 \\
6 & M & 19 & 67 & 162.2 & +2.1 & -7.0 & -8.1 \\
7 & M & 24 & 69 & 155.6 & +1.8 & -3.9 & -7.4 \\
8 & M & 36 & 60 & 155.1 & +3.6 & -13.5 & -10.2 \\
\hline
\end{tabular}


The heptane extracts were washed twice with $1 \mathrm{ml}$ of $0.1 \mathrm{~N}$ $\mathrm{NaOH}$ to remove glucose- $1-{ }^{14} \mathrm{C}$ or pyruvate- $3-{ }^{14} \mathrm{C}$. $1 \mathrm{ml}$ of the washed heptane layer was counted to determine the radioactivity in "triglyceride," and $2 \mathrm{ml}$ was hydrolyzed in $10 \%$ alcoholic potassium hydroxide for $1 \mathrm{hr}$ at $60^{\circ} \mathrm{C}$. The hydrolysates were cooled and acidified, and the fatty acids were extracted three times with equal volumes of heptane. The heptane washes were pooled in a counting vial and allowed to evaporate before the liquid scintillator was added (9). Glyceride-glycerol was calculated from the difference between total counts found in the "triglyceride" extract and those found in the fatty acids after hydrolysis.

Metabolism of sn-glycerophosphate. Approximately $4 \mathrm{~g}$ of adipose tissue was homogenized in three volumes of ice-cold $0.25 \mathrm{M}$ sucrose with a TenBroeck homogenizer and centrifuged at $1000 \mathrm{~g}$ in the cold. For preparation of mitochondria, the fluid layer between the pellet and fat cake was centrifuged at $15,000 \mathrm{~g}$ in a refrigerated centrifuge (International Equipment Co., Needham Heights, Mass.). The supernatant from the first centrifugation and the mitochondria were used for assay of enzymatic activities. All assays involved the measurement of nitrotetraformazan formed by the transfer of hydrogen to iodonitrotetrazolium. Two methods $(4,10)$ were compared and no significant differences were found. Since the method of Fried, Greenberg, and Antopol (10) allowed comparison of the soluble and insoluble forms of the sn-glycerol-3-phosphate dehydrogenases in the same homogenate, this method was selected. All incubations were carried out in counting vials in a total volume of $2 \mathrm{ml}$. Each vial contained $0.2 \mathrm{ml}$ of $0.5 \mathrm{M} \mathrm{rac}-$ glycerol-3-phosphate, $0.3 \mathrm{ml}$ of $0.4 \%$ iodonitrotetrazolium (2-p-iodo-3-p-nitro-5-phenyl tetrazolium chloride, Sigma Chemical Co., St. Louis, Mo.) and $0.2 \mathrm{ml}$ of homogenate. Medium A contained in addition $0.2 \mathrm{ml}$ of $15 \mathrm{~mm}$ nicotinamide adenine dinucleotide $\left(\mathrm{NAD}^{+}\right)$and buffer $(1.15 \mathrm{M}$ phosphate, $\mathrm{pH} 8$ ) to make $2 \mathrm{ml}$. In Medium $\mathrm{B} \mathrm{NAD}^{+}$was replaced by buffer. Medium $\mathrm{C}$ contained $0.2 \mathrm{ml}$ of $\mathrm{NAD}^{+}$, $0.2 \mathrm{ml}$ of $10^{-8} \mathrm{M} \mathrm{NaCN}, 0.2 \mathrm{ml}$ of $10^{-4} \mathrm{M}$ phenazine methosulfate and buffer to make $2 \mathrm{ml}$. Medium D was identical with medium $\mathrm{C}$, except that $\mathrm{NAD}^{+}$was omitted and replaced by buffer. After incubation for $15 \mathrm{~min}$, the reaction was stopped by adding $0.2 \mathrm{ml}$ of $30 \%$ trichloroacetic acid (TCA). The iodonitroformazan was extracted into $5 \mathrm{ml}$ of ethylacetate and the optical density determined at 490 $\mathrm{m} \mu$. Protein in the homogenate or mitochondria was determined by the biuret method (11).

Calculations. The conversion of substrate into product was calculated from the specific activity of the substrate and the radioactivity of the product. Statistical comparisons were made by use of paired differences or group means analyzed with Student's " $t$ " test.

\section{RESULTS}

Changes in body weight and oxygen consumption. During the first period seven of the eight patients gained an average of $4.2 \mathrm{~kg}$ (Table I). The one patient who lost weight had marked pitting edema at the time of admission and lost $7 \mathrm{~kg}$. Oxygen consumption of five of these patients was measured and averaged $21.4 \pm 1.1$ (mean ISEM) liters of oxygen per hr with a respiratory quotient of 0.93 during the last 3 days before the fat biopsy. Two of the five patients showed an occasional value for their respiratory quotient of 1.0. During the second period, comprising 2 wk on a 900 cal diet, the

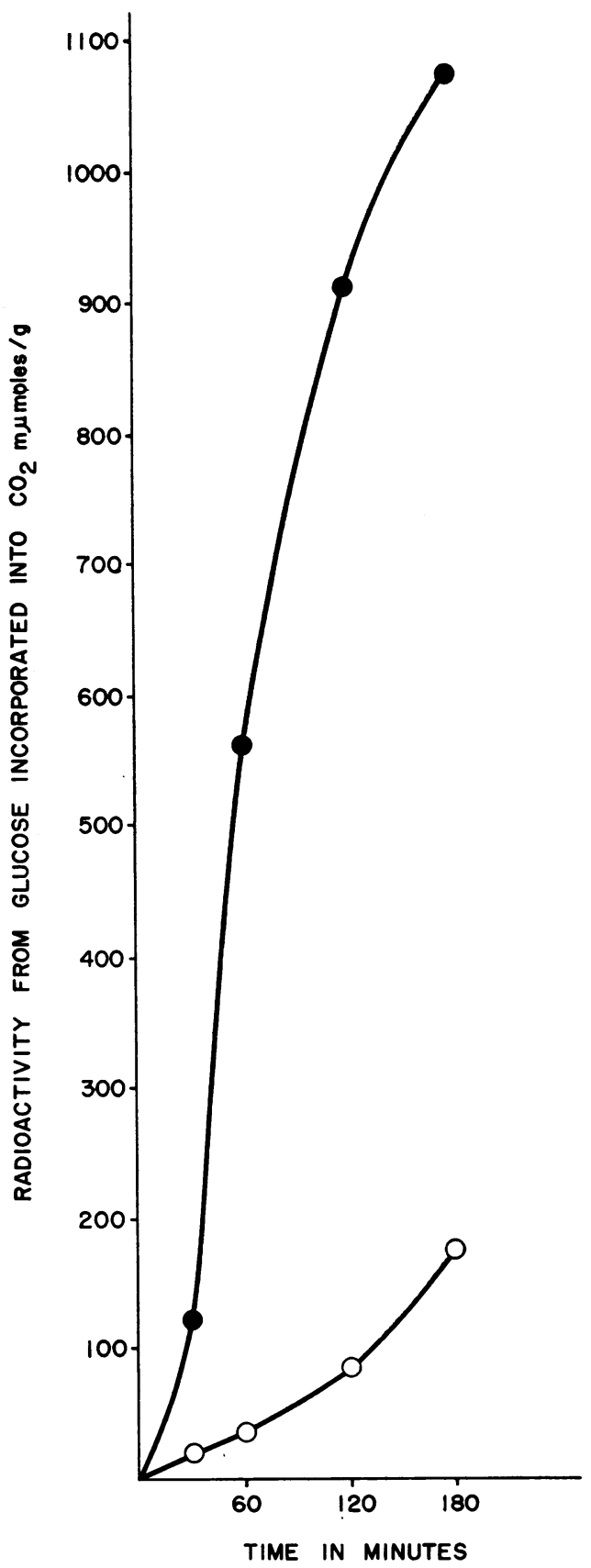

FIGURE 2 Conversion of radioactivity from glucose-1 $-{ }^{14} \mathrm{C}$ into ${ }^{14} \mathrm{CO}_{2}$ by adipose tissue from the patient who had ingested the high caloric diet before the present study. Pieces of fat weighing $120-140 \mathrm{mg}$ were incubated in KrebsRinger bicarbonate buffer containing $4 \%$ albumin, $2 \mathrm{mM}$ glucose, and $625 \mu \mathrm{U} / \mathrm{ml}$ of insulin for the times indicated. The closed circles show $\mathrm{CO}_{2}$ production from the first biopsy taken after $2 \mathrm{wk}$ on $3500 \mathrm{cal}$ and the open circles the $\mathrm{CO}_{2}$ production from the biopsy taken 2 wk after beginning the $900 \mathrm{cal}$ diet (patient No. 1). 
subjects lost an average of $9.2 \mathrm{~kg}$, the respiratory quotient dropped to between 0.70 and 0.74 , and the oxygen consumption fell to $18.5 \pm 1.7 \mathrm{liter} / \mathrm{hr}$. Administration of triiodothyronine, $250 \mu \mathrm{g} / \mathrm{day}$, in addition to the 900 cal diet, was accompanied by a further loss of weight which averaged $9.3 \mathrm{~kg}$. Oxygen consumption in the third period rose to $22.6 \pm 1.0 \mathrm{liter} / \mathrm{hr}$; and the respiratory quotient rose to $0.86 \pm 0.05$. Few symptomatic complaints could be elicited during the period of treatment with this dose of triiodothyronine.

Effects of diet and insulin on the metabolism of radioactive glucose. The most striking effects of dietary restriction on the metabolism of adipose tissue were observed in the biopsies from the patient who had ingested 5000-7000 cal daily for 6 wk before the present study was begun (Figs. 2 and 3 ). The rate of incorporation of radioactivity into $\mathrm{CO}_{2}$ (Fig. 2) and long-chain fatty acids (Fig. 3) in the presence of insulin (625 $\mu \mathrm{U} / \mathrm{ml}$ ) was constant over $3 \mathrm{hr}$. The $900 \mathrm{cal}$ diet reduced this rate even in the presence of insulin. The dose-response between insulin and the incorporation of radioactivity from glucose-1 $-{ }^{14} \mathrm{C}$ into long-chain fatty acids is shown in Fig. 4. Insulin, $19 \mu \mathrm{U}$, increased the conversion of radioactivity into fatty acids, and there was a further dose-related increase over the range of insulin concentrations tested. At the highest concentration $(625 \mu \mathrm{U} / \mathrm{ml}) 50 \mathrm{~m} \mu$ moles of radioactive glucose

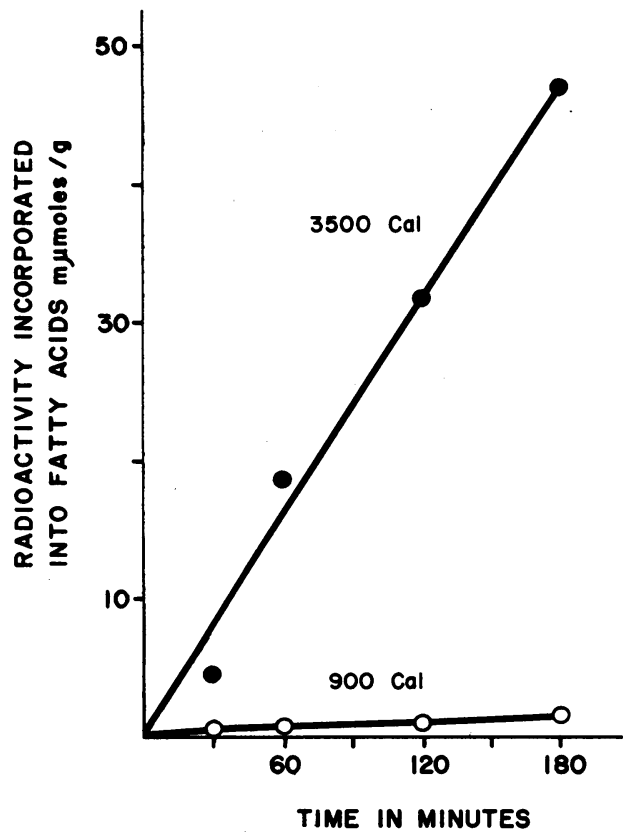

FIgURE 3 Conversion of radioactivity from glucose- $1-{ }^{14} \mathrm{C}$ into ${ }^{14} \mathrm{C}$-labeled fatty acids by adipose tissue from the patient who had ingested the high calorie diet before the present study. The fatty acids were isolated from the same tissues for which $\mathrm{CO}_{2}$ production was measured in Fig. 2.

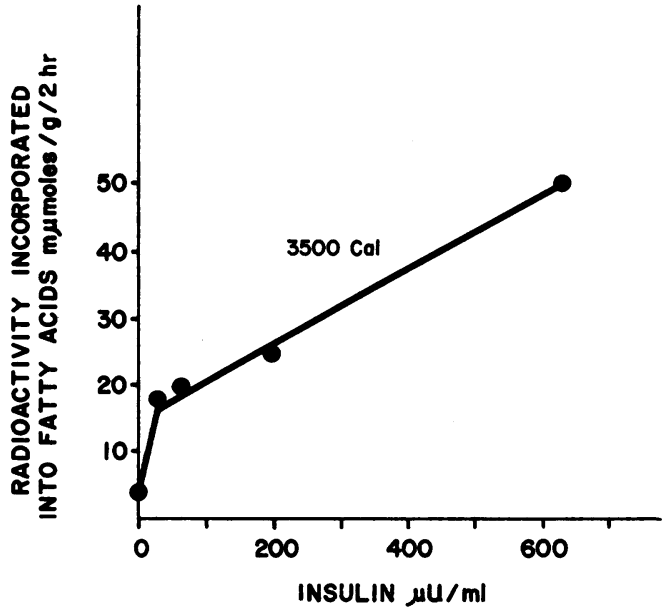

FIGURE 4 Relationship between the conversion of radioactivity from glucose-1 $1{ }^{14} \mathrm{C}$ into fatty acids and the concentration of insulin in the medium. Pieces of fat were obtained from the first biopsy (Fig. 1) of the patient who had ingested the high calorie diet before the present study. All incubations were $2 \mathrm{hr}$ in length.

was incorporated into long-chain fatty acids during the $2 \mathrm{hr}$ incubation.

The fat from four patients was used to compare the effects of insulin on fat cells and on pieces of fat (Figs. $5-7)$. The rate of conversion of radioactivity from glucose- $1-{ }^{14} \mathrm{C}$ into ${ }^{14} \mathrm{CO}_{2}$ was constant over the $3 \mathrm{hr}$ during which fat cells or fat pads were incubated (Figs. 5 and 7). The addition of insulin, $625 \mu \mathrm{U} / \mathrm{ml}$, significantly augmented the formation of ${ }^{14} \mathrm{CO}$, by pieces of fat at 60,120 , and $180 \mathrm{~min}(P<0.05)$ (Fig. 5, left) but was without detectable effect on the oxidation of glucose by fat cells (Fig. 5, right). The rate of conversion of radioactivity from glucose-1- ${ }^{14} \mathrm{C}$ into glyceride-glycerol was also constant with time (Fig. 6), and the addition of insulin significantly increased the quantity of radioactivity incorporated into this compound by fat pads at 30 and 60 min (Fig. 6, left), but insulin had no significant effect on fat cells. The biopsies during caloric restriction whether before or during treatment with triiodothyronine (periods 2 and 3 ) had a reduced rate of conversion of glucose-1 $1{ }^{14} \mathrm{C}$ into $\mathrm{CO}_{2}$ and insulin was without effect (Fig. 7).

The dose-response between insulin and the oxidation of glucose was assessed in fat pads from five patients (Figs. 8 and 9). More $\mathrm{CO}_{2}$ and glyceride-glycerol was produced in the presence of insulin with effects at concentrations of 19 and $62 \mu \mathrm{U} / \mathrm{ml}$. It is clear that the 900 cal diet with or without triiodothyronine completely eliminated the effects of insulin on the conversion of glucose to $\mathrm{CO}$ (Fig. 8). The $900 \mathrm{cal}$ diet also inhibited the effects of insulin on the conversion of glucose into 

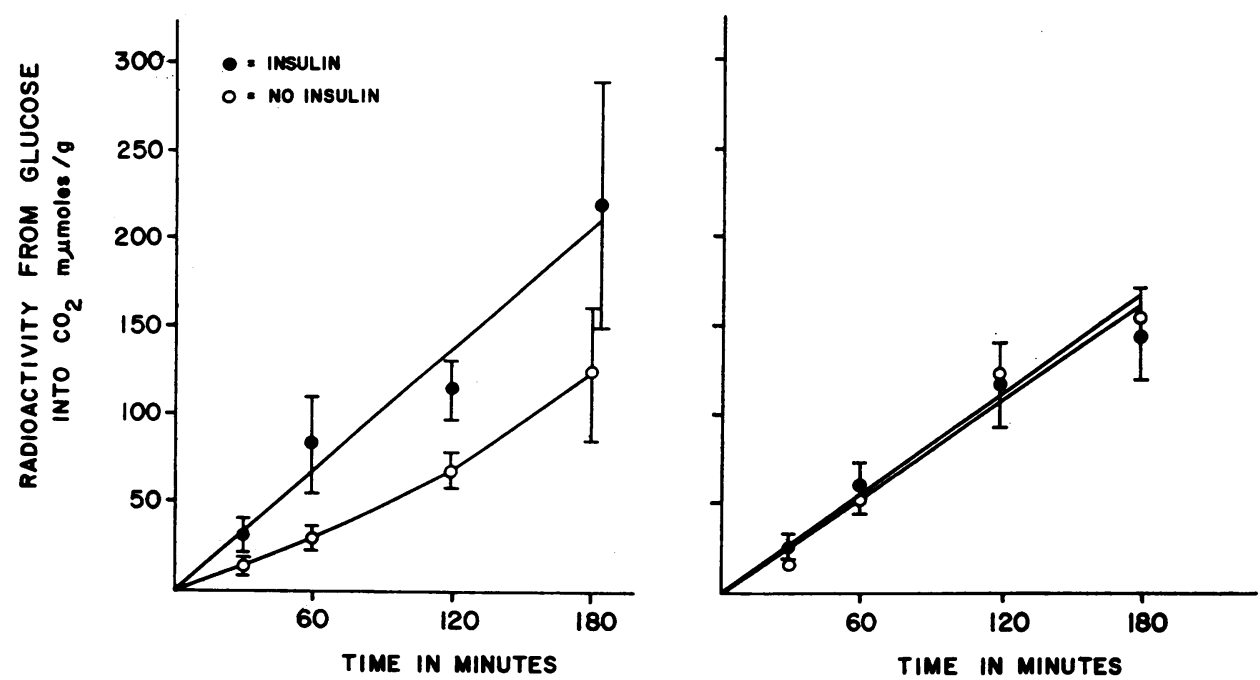

FIGURE 5 Incorporation of radioactivity from glucose-1 ${ }^{14} \mathrm{C}$ into $\mathrm{CO}_{2}$ by pieces of fat (left) and fat cells (right) prepared from the first biopsy. Fat pads and fat cells were incubated in Krebs-Ringer bicarbonate buffer containing $4 \%$ albumin and $2 \mathrm{~mm}$ glucose-1-14 $\mathrm{C}$ for the indicated times. The incubations represented by the closed circles contained insulin, $625 \mu \mathrm{U} / \mathrm{ml}$. Each point is the mean of incubations from four patients, and vertical lines are the standard error (patients $5,6,7$, and 8 ).

glyceride-glycerol, but triiodothyronine restored this response to insulin to near normal levels (Fig. 9).

Lipogenesis from pyruvate. The incorporation of radioactivity from pyruvate-3- ${ }^{14} \mathrm{C}$ into $\mathrm{CO}_{2}$, glycerideglycerol, and long-chain fatty acids was measured in fat cells obtained from fat biopsies performed at the end of periods 1,2 , and 3 in seven patients (Table II). Insulin alone did not enhance the conversion of radioactivity into any product. The addition of glucose, with or without insulin, significantly stimulated the incorporation
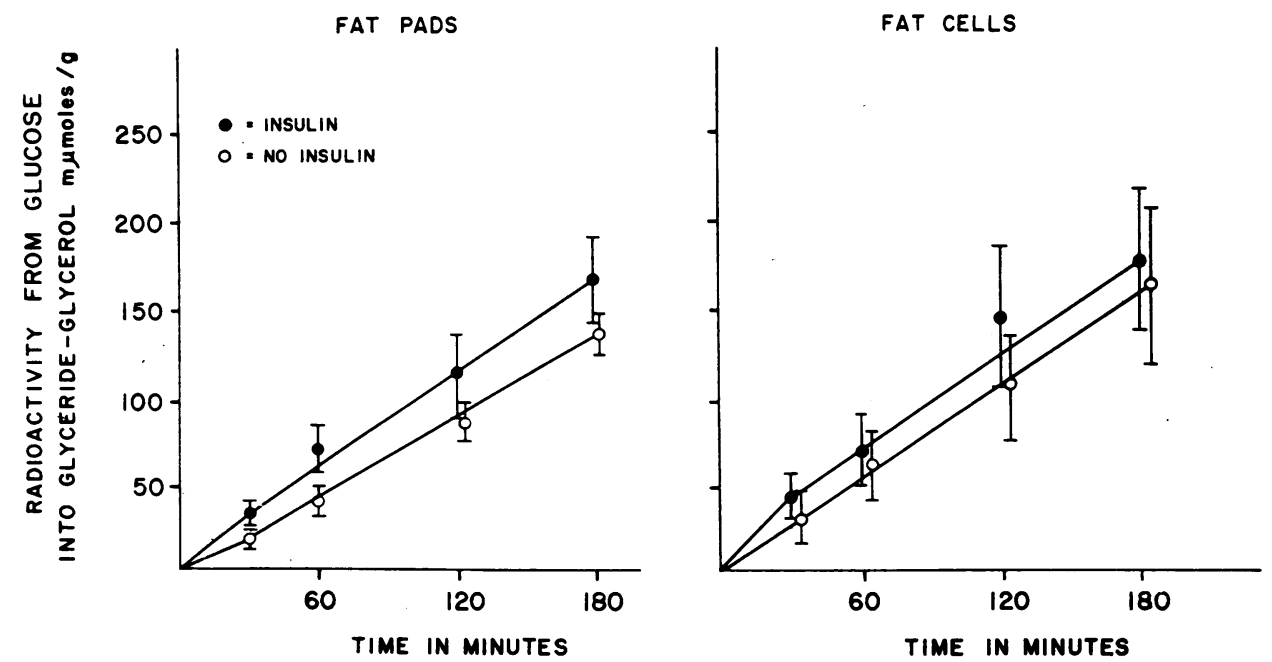

FIGURE 6 Incorporation of radioactivity from glucose-1 $-{ }^{14} \mathrm{C}$ into glyceride-glycerol by pieces of fat (left) and fat cells (right) from the first biopsy. The glyceride-glycerol was isolated from the same tissues for which $\mathrm{CO}_{2}$ production was measured in Fig. 5. The incubations represented by the closed circles contained insulin $(625 \mu \mathrm{U} / \mathrm{ml})$. Each point is the mean of incubations from four patients, and the vertical lines are the standard errors (patients 5 , 6,7 , and 8). 
$900 \mathrm{Cal}$

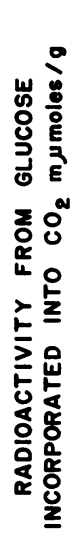

FAT PADS
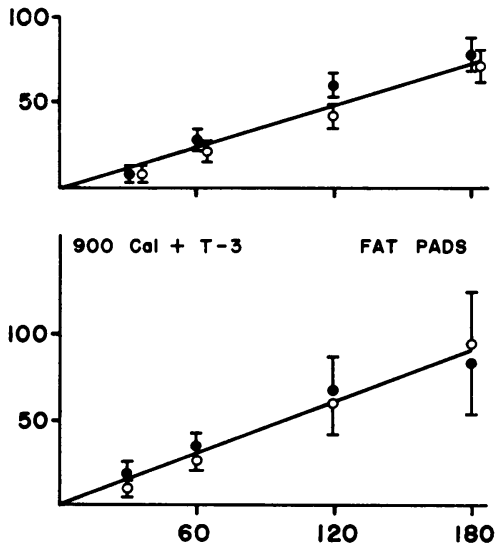

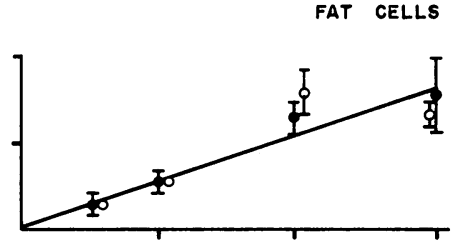

FAT CELLS

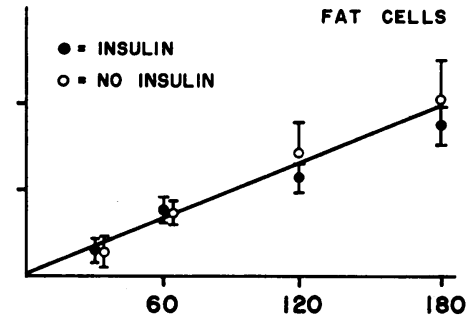

TIME IN MINUTES

FIGURE 7 Incorporation of radioactivity from glucose-1- ${ }^{14} \mathrm{C}$ into $\mathrm{CO}_{2}$ by pieces of fat and fat cells. The upper pair of graphs were from the second biopsy and the lower pair from the third biopsy. Incubations were carried out in Krebs-Ringer bicarbonate buffer containing $4 \%$ albumin and $2 \mathrm{~mm}$ glucose- $1-{ }^{14} \mathrm{C}$ for the indicated times. The incubations represented by the closed circles contained insulin, 625 $\mu \mathrm{U} / \mathrm{ml}$. Each point is the mean of incubations from four patients, and the vertical lines are the standard error (patients $5,6,7$, and 8 ).

of radioactivity from pyruvate into long-chain fatty acids. These effects of glucose on the stimulation of fatty acid synthesis from pyruvate were most striking in the patient fed 5000-7000 cal daily for $6 \mathrm{wk}$. In her first biopsy (not included in Table II) glucose and insulin stimulated a 10-fold increase in conversion of radioactivity from pyruvate into long-chain fatty acids (5.0$56.6 \mathrm{~m} \mu$ moles $/ \mathrm{g}$ per $2 \mathrm{hr}$ ), and glucose alone stimulated a 6-fold increase (7.9-48.6 $\mathrm{m} \mu$ moles/g per $2 \mathrm{hr}$ ).

Caloric restriction reduced the incorporation of radioactivity from pyruvate into fatty acids by $30-90 \%$ and reduced its oxidation to $\mathrm{CO}_{2}$ and conversion to glycerideglycerol. During treatment with triiodothyronine pyruvate conversion to fatty acids and $\mathrm{CO}_{2}$ was returned toward the values from the first biopsy. However, in contrast to the first biopsy glucose and insulin did not enhance the incorporation of radioactivity from pyruvate into fatty acids (Table II).

Effects of triiodothyronine on glycerol-3-phosphate oxidation. The effects of triiodothyronine and of caloric restriction on the metabolism of sn-glycerol-3-phosphate by homogenates of adipose tissue are summarized in Table III. Dietary restriction (period 1 vs. 2) significantly reduced the metabolism of rac-glycerol-3-phosphate in media $\mathrm{B}, \mathrm{C}$, and $\mathrm{D}$, but medium $\mathrm{A}$ was unaffected. During treatment with triiodothyronine, the enzymatic activity of media $A, B$, and $D$ was significantly augmented, but medium $C$ remained at the same low level observed after period 2. The effects of caloric restriction and triiodothyronine on the isolated mitochondria incubated in medium $\mathrm{D}$ were similar to those seen with the whole homogenate, but the values were larger because the protein content was lower.

\section{DISCUSSION}

These experiments have explored the effects of caloric intake and treatment with triiodothyronnie on the metabolism of adipose tissue. A 3500 cal diet was selected for the first period because previous studies on the energy expenditure of obese patients (unpublished observations) had shown that this level of caloric intake was above that required for weight maintenance. Thus, during the first period (Fig. 1) all patients were in positive caloric balance. A negative caloric balance was induced in the second and third periods. The measurements of oxygen consumption provided evidence supporting this assessment of energy balance (12). It was surprising that oxygen consumption, which declined in the second period, was no higher at the end of treatment with triiodothyronine, $250 \mu \mathrm{g} /$ day, than during the first period. However, this small calorigenic effect was matched by the paucity of clinical symptoms elicited during treatment with triiodothyronine.

Fat biopsies providing up to $30 \mathrm{~g}$ of subcutaneous fat were obtained from the abdominal panniculus incision. With this quantity of tissue it was possible to perform incubations with fat pads to make isolated fat cells and, at the same time, to prepare homogenates of adipose tissues. Fat cells were readily obtained from these biopsies with little or no evidence of breakage during the procedure. The viability of these fat cells has been 
shown previously by the fact that oxygen consumption was linear for periods up to $4 \mathrm{hr}$.

The metabolism of sn-glycerol-3-phosphate was evaluated in homogenates of adipose tissue by a method which allowed comparison of the soluble and mitochondrial sn-glycerol-3-phosphate dehydrogenases. The mitochondrial enzyme catalyzes the transfer of hydrogen from glycerophosphate to flavin adenine dinucleotide (FAD) and is to be distinguished from the soluble or cytoplasmic sn-glycerol-3-phosphate dehydrogenase which requires $\mathrm{NAD}^{+}$as a cofactor (Fig. 10). It is the activity of the mitochondrial enzyme which is reduced in subcutaneous adipose tissue of obese subjects (1). This same enzyme increases in activity with thyroid treatment in some species $(4,5)$, though not in all (13). The experiments reported in Table III (medium D) show that pretreatment with triiodothyronine increased the activity of this enzyme in human fat. The soluble enzyme was not influenced by thyroid hormone but was higher on the 3500 cal diet (Table III, medium C). This latter finding is in agreement with the observations of Tepperman and Tepperman (6), who found that refeeding fasted rats increased the activity of the soluble sn-glycerol-3-phosphate dehydrogenase.

The activity of the mitochondrial sn-glycerol-3-phosphate dehydrogenase in fat at the end of period 1 was not significantly different from the activity in fat from normal patients obtained from the operating room (8.6

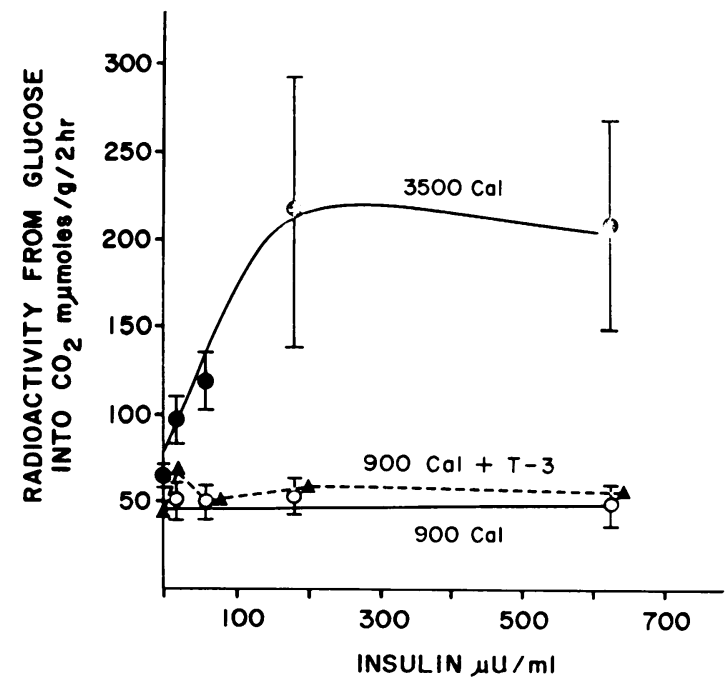

Figure 8 Relationship between the conversion of radioactivity from glucose $-1-{ }^{14} \mathrm{C}$ to $\mathrm{CO}_{2}$ and the concentration of insulin in the incubation medium. Pieces of fat were obtained from the first biopsy (closed circles), the second biopsy (open circles), or the third biopsy (solid triangles) and incubated for $2 \mathrm{hr}$ in Krebs-Ringer bicarbonate buffer with $4 \%$ albumin and $2 \mathrm{~mm}$ glucose $-1-{ }^{14} \mathrm{C}$. Each point is the mean of incubations from four patients, and the vertical lines are the standard errors (patients 2, 3, 5, 6, and 7).

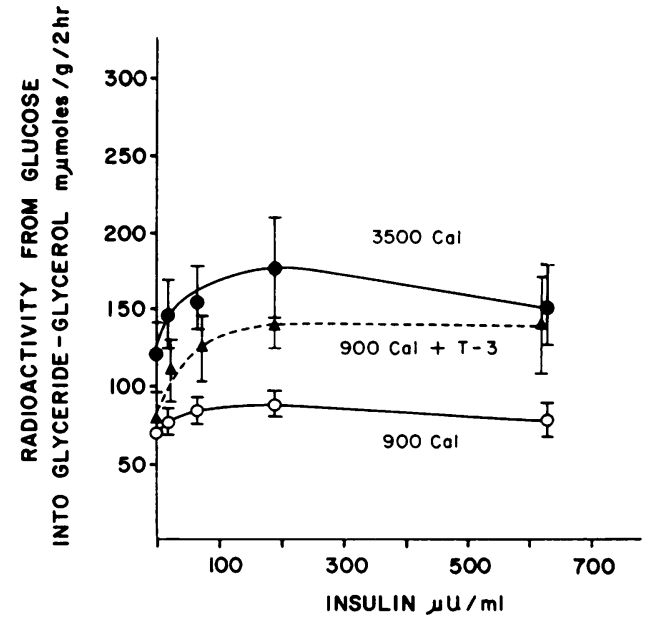

Figure 9 Relationship between the conversion of radioactivity from glucose $-1-{ }^{14} \mathrm{C}$ to glyceride-glycerol, and the concentration of insulin in the incubation medium. The glyceride-glycerol was isolated from the same tissues for which $\mathrm{CO}_{2}$ production was measured in Fig. 8 . The incubations presented by the closed circles were from the first biopsy, the incubations represented by the open circles from the second biopsy, and those from the third biopsy by closed triangles. Each point is the mean of incubations from four patients, and the vertical lines are the standard errors (patients $2,3,5,6$, and 7 ).

$\pm 1.6 \mu \mathrm{g}$ of iodonitroformazan per $\mathrm{mg}$ of protein per $15 \min [\mathrm{n}=6]$ ), but the activity from the second biopsy was significantly reduced. Comparison of data on obese patients who were in positive caloric balance (Fig. 1) with clata on patients undergoing operation and who were probably in negative caloric balance may be misleading. Reexamination of the records of patients whose biopsies formed the basis of an earlier report (14) showed that almost all of them had been in negative caloric balance before the biopsy. These data and the data from the second biopsy (Fig. 2) probably provide a better comparison for fat from patients undergoing surgery than the fat from the overfed patients. To settle this point studies are underway to measure the activity of mitochondrial sn-glycerol-3-phosphate dehydrogenase in normal and obese patients with comparable caloric intake.

The net effect of the mitochondrial glycerophosphate cycle, shown in Fig. 10 is to transfer hydrogen from extramitochondrial $\mathrm{NADH}$ (reduced form of $\mathrm{NAD}^{+}$) intramitochondrial receptors. The $\mathrm{P}: \mathrm{O}$ ratio for this oxidative pathway is less than 2 (15) compared to a $\mathrm{P}: \mathrm{O}$ ratio of 3 for the oxidation of glucose to $\mathrm{CO}_{2}$ through the Krebs cycle (16). The glycerophosphate pathway, therefore, could serve as a regulator of the efficiency with which oxidation and phosphorylation are coupled. Increased activity of this pathway during high caloric intake would tend to decrease the caloric effi- 
TABLE II

Effect of Glucose and Insulin on the Incorporation of Radioactivity from Pyruvate-3-14C into $\mathrm{CO}_{2}$ and Lipid by Adipose Cells

\begin{tabular}{|c|c|c|c|c|c|c|c|c|c|c|c|}
\hline \multirow{2}{*}{$\begin{array}{l}\text { Additions to } \\
\text { medium } \\
\text { Biopsy No....... }\end{array}$} & \multicolumn{5}{|c|}{ Fatty acids } & \multicolumn{3}{|c|}{$\mathrm{CO}_{2}$} & \multicolumn{3}{|c|}{ Glyceride-glycerol } \\
\hline & 1 & & & 2 & 3 & 1 & 2 & 3 & 1 & 2 & 3 \\
\hline & & \multicolumn{10}{|c|}{ mumoles $/ \mathrm{g}$ triglyceride $/ 2 \mathrm{hr}$} \\
\hline None & $1.2 \pm 0.5^{*}$ & \multirow[t]{2}{*}{$<0.05$} & 0.1 & \pm 0.34 & $1.7 \pm 0.6$ & $83 \pm 23$ & $59 \pm 15$ & $116 \pm 22$ & $158 \pm 36$ & $72 \pm 20$ & $81 \pm 29$ \\
\hline Glucose $†$ & $4.5 \pm 1.7\rfloor$ & & 0.54 & \pm 0.34 & $1.6 \pm 0.9$ & $81 \pm 29$ & $79 \pm 10$ & $120 \pm 29$ & $109 \pm 36$ & $74 \pm 35$ & $67 \pm 12$ \\
\hline Insulin§ & $1.3 \pm 0.57$ & \multirow{2}{*}{$<0.02$} & 0.46 & \pm 0.28 & $2.1 \pm 1.2$ & $95 \pm 27$ & $85 \pm 15$ & $113 \pm 30$ & $147 \pm 46$ & $67 \pm 32$ & $120 \pm 36$ \\
\hline Glucose $\dagger$ and insulin & $5.4 \pm 1.5$ & & 0.66 & \pm 0.50 & $2.2 \pm 1.2$ & $96 \pm 22$ & $50 \pm 20$ & $144 \pm 34$ & $98 \pm 28$ & $115 \pm 83$ & $110 \pm 34$ \\
\hline
\end{tabular}

* Mean \pm SEM for six patients (patients Nos. 2-6, Table I).

$\ddagger 5 \mathrm{~mm}$ glucose.

$\S$ Insulin, $625 \mu \mathrm{U} / \mathrm{ml}$.

ciency of food, thus allowing caloric wastage as heat. Recent studies by Miller, Mumford, and Stock $(17,18)$ and Stirling and Stock (19) have suggested that wasting calories may occur in normal man and animals. With human subjects they showed that high caloric intake leads to enhanced thermogenesis $(17,18)$. The present experiments provide evidence that the glycerophosphate cycle (Fig. 10) may be augmented by high caloric intake and thus supports one of the mechanisms suggested by these authors (19). Indeed, the difference between the activity of this pathway in obese and normal individuals (1) may account for the efficiency with which obese patients utilize their food. Of more importance for these patients, however, is the fact that caloric restriction reduced the activity of the glycerophosphate cycle. This reduced activity would decrease their capacity to waste calories as heat and may provide a partial explanation for the oft observed plateau during dietary restriction. Triiodothyronine prevented the drop in activity of the glycerophosphate cycle and could thus allow additional calories to be dissipated as heat.
Lipogenesis from radioactive glucose and pyruvate was examined in fat cells and fat pads from each biopsy. Demonstration of a response to insulin $(20,21)$ depends upon the preparation chosen for study (22-24), upon the previous caloric intake, as well as age (23) and the size of fat cells (25). The importance of previous nutritional status on the response to insulin was demonstrated in the present studies by comparing the response of the fat pads from the first biopsy with those from the second and third biopsies.

After $2 \mathrm{wk}$ on a high caloric intake, insulin augmented the conversion of radioactivity from glucose${ }_{1-}^{14} \mathrm{C}$ into $\mathrm{CO}_{2}$, glyceride-glycerol, and fatty acids. These effects were most marked in the patient who had ingested $5000-7000$ cal daily for 6 wk before beginning the 3500 cal diet. In her biopsy radioactivity from glucose and pyruvate was readily incorporated into longchain fatty acids and a dose-response to insulin was demonstrated. After 2 wk on a restricted intake, however, lipogenesis could no longer be demonstrated in any biopsy.

TABLE III

Effect of Diet and Triiodothyronine on the Metabolism of $\alpha$-Glycerophosphate by Homogenates of Human Adipose Tissue

\begin{tabular}{|c|c|c|c|c|c|c|}
\hline \multirow[b]{2}{*}{ Period } & \multirow[b]{2}{*}{ Diet } & \multirow[b]{2}{*}{ Treatment } & \multicolumn{4}{|c|}{ Medium } \\
\hline & & & A & B & $\mathrm{C}$ & $\mathrm{D}$ \\
\hline & & & \multicolumn{4}{|c|}{$\mu g$ INT formed $/ \mathrm{mg}$ protein $/ 15 \mathrm{~min}$} \\
\hline 1 & 3500 & - & $39 \pm 10^{*}$ & $2.3 \pm 0.4$ & $310 \pm 70$ & $7.2 \pm 0.62$ \\
\hline 2 & 900 & - & $29 \pm 11$ & $0.9 \pm 0.2$ & $169 \pm 31$ & $3.9 \pm 0.80$ \\
\hline 3 & 900 & Triiodothyronine & $54 \pm 11$ & $3.2 \pm 0.4$ & $120 \pm 21$ & $7.6 \pm 1.0$ \\
\hline \multicolumn{7}{|c|}{ Statistical comparisons, $P$ values } \\
\hline \multirow{2}{*}{\multicolumn{3}{|c|}{$\begin{array}{l}\text { Period } 1 \text { vs. } 2 \\
\text { Period } 2 \text { vs. } 3\end{array}$}} & $>0.1$ & $<0.05$ & $<0.01$ & $<0.02$ \\
\hline & & & $<0.02$ & $<0.05$ & $>0.1$ & $<0.05$ \\
\hline
\end{tabular}

$I N T$, iodonitrotetrazolium.

* Mean \pm SEM for eight patients. 


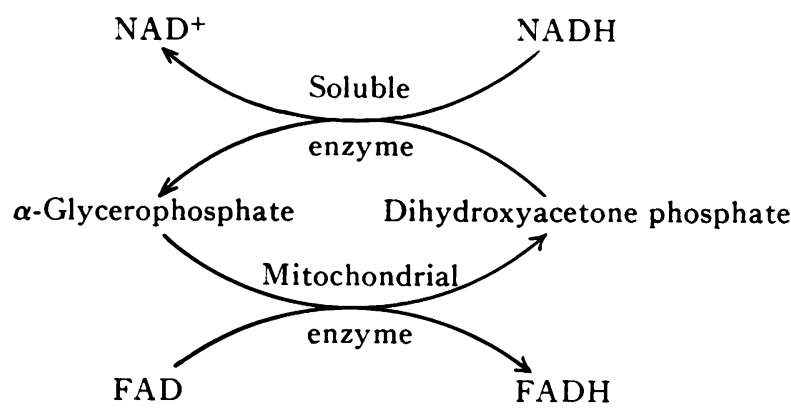

Figure 10 Glycerophosphate cycle.

Although pieces of fat responded to insulin no effects of insulin could be detected with fat cells. In this respect our data are similar to the observation of Gries and Steinke (23), who demonstrated a greater response in pieces of fat than in fat cells. Together these observations support the concept that the trauma involved in preparing fat cells might impair their sensitivity to insulin. Hirsch and Goldrick (26) proposed a similar explanation for the variable responses to insulin which they observed with samples of fat obtained by needle aspiration. Further support for this concept was provided by Björntorp and Martinsson (22) who demonstrated differences in response to insulin between pieces of fat and aspiration biopsies. It would thus appear that the needle aspiration biopsy behaves more like our preparation of fat cells than like the pieces of fat cut from a larger biopsy.

Age of the fat donor and the size of the fat cells are two additional variables which may influence the response to insulin. Gries and Steinke (23) and Salans, Knittle, and Hirsch (25) have demonstrated that lipogenesis in human adipose tissue decreases with age. In the present studies on obese patients the ages ranged from 19 to $42 \mathrm{yr}$, but most of the patients were under 30 , and they all clearly responded to insulin.

The observations of Salans, Knittle, and Hirsch (25) would lead us to assume that our patients had an increased number of fat cells. Although the size of fat cells was not measured, it would seem reasonable to assume that they were also larger than normal, and that they decreased in size during the periods of caloric restriction (periods 2 and 3 ). Yet, the maximal response to insulin was detected at the end of the first period when the cells should have been largest. It should be noted that the data of Salans et al. did not demonstrate an effect of insulin on the incorporation of radioactivity into long-chain fatty acids or into triglyceride (presumably glyceride-glycerol) but only on $\mathrm{CO}_{2}$. From our studies it is clear that the sensitivity of fat cells from obese patients is dependent not only on their size but upon the previous caloric intake, and that even very large fat cells can become sensitive to insulin.

Pyruvate (27-30) can supply carbon for the synthesis of fatty acids and sn-glycerol-3-phosphate in adipose tissue. The addition of nonradioactive glucose to the incubation medium containing fat cells augmented the conversion of radioactivity from pyruvate- $3{ }^{14} \mathrm{C}$ into fatty acids and reduced the conversion to glyceride-glycerol. This stimulatory effect of glucose on lipogenesis from pyruvate has been attributed to the supply of sn-glycerol3 -phosphate and NADPH (reduced form of NADP) which are made available from glucose $(27,28)$. Indeed, lipogenesis from pyruvate could be demonstrated in the present experiment with fat cells from the first biopsy under conditions in which no measurable radioactivity from glucose was incorporated into fatty acids. It is possible that pyruvate represents a more important source of carbon for synthesis of long-chain fatty acids than does glucose.

Pretreatment with thyroid hormone increased lipolysis by adipose tissue incubated in vitro $(31,32)$ and elevated the levels of circulating free fatty acids in vivo (33). Lipogenesis is also enhanced by this treatment (34). In the obese patient treated with triiodothyronine the effects of insulin on the incorporation of radioactivity from glucose into glyceride-glycerol were increased, but there was no effect on the oxidation of glucose to $\mathrm{CO}_{2}$. This latter finding is in agreement with earlier studies from this laboratory in which thyroid hormones increased lipolysis (32) and lipogenesis (34) without affecting glucose oxidation (35).

\section{ACKNOWLEDGMENTS}

The author thanks Dr. E. B. Astwood for his continuing encouragement and support. Dr. T. Gallagher, Jr., and Dr. J. $H$. Londono kindly helped with some of the biopsies. The author is particularly grateful to Dr. C. P. Powell for the opportunity to study three patients under his care at the Lemuel Shattuck Hospital.

This work was supported in part by grants AM-09897 and FR-54 from the National Institutes of Health.

\section{REFERENCES}

1. Galton, D. J., and G. A. Bray. 1967. Metabolism of $\alpha$-glycerol phosphate in human adipose tissue in obesity. J. Clin. Endocrinol. Metab. 27: 1573.

2. Howard, C. F., Jr., and J. M. Lowenstein. 1965. The effect of glycerol 3-phosphate on fatty acid synthesis. J. Biol. Chem. 240: 4170.

3. Galton, D. J. 1968. Lipogenesis in human adipose tissue. J. Lipid Res. 9: 19.

4. Lee, Y-P., and H. A. Lardy. 1965. Influence of thyroid hormones on $\mathrm{L}-\alpha$-glycerophosphate dehydrogenases and other dehydrogenases in various organs of the rat. $J$. Biol. Chem. 240: 1427.

5. Tarentino, A. L., D. A. Richert, and W. W. Westerfield. 1966. The concurrent induction of hepatic $\alpha$-glycero- 
phosphate dehydrogenase and malate dehydrogenase by thyroid hormone. Biochim. Biophy's. Acta. 124: 295.

6. Tepperman, H. M., and J. Tepperman. 1968. Adaptive changes in $\alpha$-glycerophosphate generating enzymes in rat liver. Amer. J. Physiol. 214: 67.

7. Rodbell, M. 1964. Metabolism of isolated fat cells. I. Effects of hormones on glucose metabolism and lipolysis. J. Biol. Chem. 239: 375.

8. Dole, V. P. 1956. A relation between non-esterified fatty acids in plasma and the metabolism of glucose. J. Clin. Invest. 35: 150.

9. Bray, G. A. 1960. A simple efficient liquid scintillator for counting aqueous solutions in a liquid scintillation counter. Anal. Biochem. 1: 279.

10. Fried, G. H., N. Greenberg, and W. Antopol. 1961. Determination of alpha-glycerophosphate oxidation with tetrazolium. Proc. Soc. Exp. Biol. Med. 107: 523.

11. Gornall, A. G., C. J. Bardawill, and M. M. David. 1949. Determination of serum proteins by means of the biuret reaction. J. Biol. Chem. 177: 751 .

12. Lusk, G. 1928. The Elements of the Science of Nutrition. W. B. Saunders Company, Philadelphia. 4th edition.

13. Kleitke, B., G. Heier, and A. Wollenberger. 1966. Influence of thyroxine treatment on the activity of mitochondrial $\alpha$-glycerophosphate dehydrogenase in liver, heart and skeletal muscle of several mammalian species. Biochim. Biophys. Acta. 130: 270.

14. Galton, D. J., 1966. An enzymatic defect in a group of obese patients. Brit. Med. J. 2: 1498.

15. Smith, R. E. 1964. Thermogenesis and thyroid action. Nature (London). 204: 1311.

16. Wieland, O. 1968. Ketogenesis and its regulation. In Advances in Metabolic Disorders. R. Levine and R. Luft, editors. Academic Press Inc., New York. 3: 1.

17. Miller, D. S., and P. Mumford. 1967. Gluttony. I. An experimental study of overeating low- or high-protein diets. Amer. J. Clin. Nutr. 20: 1212.

18. Miller, D. S., P. Mumford, and M. J. Stock. 1967. Gluttony. II. Thermogenesis in overeating man. Amer. J. Clin. Nutr. 20: 1223.

19. Stirling, J. L., and M. J. Stock. 1968. Metabolic origins of thermogenesis induced by diet. Nature (London). 220: 801 .

20. Fessler, A., and J. C. Beck. 1965. The effect of insulin on the metabolism of human adipose tissue in vitro. Biochim. Biophys. Acta. 106: 199.

21. Kahlenberg, A., and N. Kalant. 1964. The effect of insulin on human adipose tissue. Can. J. Biochem. 42: 1623.
22. Björntorp, P., and A. Martinsson. 1967. Conversion of glucose $-{ }^{14} \mathrm{C}$ into carbon dioxide and lipids in different specimens of human subcutaneous adipose tissue. Acta Med. Scand. 181: 359.

23. Gries, F. A., and J. Steinke. 1967. Comparative effects of insulin on adipose tissue segments and isolated fat cells of rat and man. J. Clin. Invest. 46: 1413.

24. Hirsch, J., and R. B. Goldrick. 1964. Serial studizs on the metabolism of human adipose tissue. I. Lipogenesis and free fatty acid uptake and release in small aspirated samples of subcutaneous fat. J. Clin. Invest. 43: 1776

25. Salans, L. B., J. L. Knittle, and J. Hirsch. 1968. The role of adipose cell size and adipose tissue insulin sensitivity in the carbohydrate intolerance of human obesity. J. Clin. Invest. 47: 153.

26. Hirsch, J., and B. Goldrick. 1965. Metabolism of human adipose tissue. In Handbook of Physiology. Section 5. Adipose tissue. A. E. Renold and G. F. Cahill, Jr., editors. American Physiological Society, Washington, D. C. 455.

27. Winegrad, A. I., and A. E. Renold. 1958. Studies on rat adipose tissue in vitro. I. Effect of insulin on the metabolism of glucose, pyruvate and acetate. J. $B^{\circ}$ ol. Chem. 233: 267.

28. Bray, G. A. 1968. Lipogenesis from glu:ose and pyruvate in fat cells from genetically obese rats. J. Lipid Res. 9: 681.

29. White, L. W., H. R. Williams, and B. R. Landau. 1968. Metabolism of pyruvate by rat adipose tissue in vitro. Arch. Biochem. Biophys. 126: 552.

30. Kneer, P., and E. G. Ball. 1968. Studies on the metabolism of adipose tissue. XXI. An evaluation of the major pathways of pyruvate metabolism. J. Biol. Chem. 243: 2863.

31. Debons, A. F., and I. L. Schwartz. 1961. Dependence of the lipolytic action of epinephrine in vitro upon thyroid hormone. J. Lipid Res. 2: 86.

32. Bray, G. A., and H. M. Goodman. 1965. Studies on the early effects of thyroid hormones. Endocrinology. 76: 323.

33. Rich, C., E. L. Bierman, and I. L. Schwartz. 1959. Plasma nonesterified fatty acids in hyperthyroid states. J. Clin. Invest. 38: 275.

34. Bray, G. A., and H. M. Goodman. 1968. Metabolism of adipose tissue from normal and hypothyroid rats. Endocrinology $82: 860$.

35. Goodman, H. M., and G. A. Bray. 1966. Role of thyroid hormones in lipolysis. Amer. J. Physiol. 210: 1053. 